(being a private hospital) where often the most difficult patients are admitted.

The situation with restricted patients is different. The RMO has no authority to discharge the patient, although the Home Office could be accused of passing the buck. It is unfair that administrative officers and clerks, hundreds of miles away at the Home Office, should make this decision for some of the most difficult, complicated and dangerous patients. In our experience, the Home Office delegates this responsibility to consider and order conditional discharge of a restricted patient to the tribunal. Once again, one of us (AK) has experienced a $100 \%$ concordance in his view as the RMO and the tribunal decision. Over the past four years, 15 tribunals were held for restricted patients under his care and in six cases a conditional discharge was recommended and granted.

With regard to the attendance of the RMO at tribunals, we agree with Wood that the RMO should be available to give evidence. The tribunal dates are fixed after negotiation and agreement with the RMO who should not delegate this responsibility to juniors. Attendance at the tribunals by junior doctors as observers is a valuable experience. For unrestricted patients, junior doctors may be asked to write psychiatric reports for the tribunal (under supervision) and give verbal evidence. But the RMOs should make themselves available if the tribunal wishes to consult the RMO on issues where only a RMO can make a decision.

MeEna Agarwal, Queen Elizabeth Hospital, Gateshead, Tyne \& Wear, NE9 6SX and *ANIL KUMAR, Calderstones Hospital, Whalley, Clitheroe, BB7 9PE

*Correspondence

\section{Propofol and electroconvulsive therapy}

The finding by Bentham \& Callinan (Psychiatric Bulletin, June 1994 18, 374) of an association between propofol and a higher number of shorter seizures compared with methohexitone is not surprising. It is now well established that propofol should not be used for ECT. Although it has many good features such as smooth induction of anaesthesia and rapid and complete recovery, its potential to reduce setzure activity contraindicates its use for ECT (Simpson et al, 1988). Methohexitone is the agent of choice, in a dose of $0.75-1.0 \mathrm{mg} / \mathrm{kg}$ but at higher doses it also decreases seizure length (Miller et al, 1985). It is therefore not sufficient simply to advise that propofol should not be used with the implication that methohexitone is devoid of any problems. In addition, the degree of oxygenation/ventilation. the type of psychoactive drugs that are prescribed and other factors such as age and gender, all need to be borne in mind when assessing a patient who has had short/unsatisfactory seizures during ECT.

MILLER, A.L., FABER, R.A., HATCH, J.P. \& ALEXANDER, H.E. (1985) Factors affecting amnesia, selzure duration and efficacy in ECT. American Journal of Psychtatry. 142. 692-696.

Simpson, K.H., Halsall, P.J., Carr, C.M.E. \& Stewart, K.G. (1988) Propofol reduces seizure duration in patients having anaesthesia for ECT. British Journal of Anaesthesta. 61, 343-344.

S. CURRAN, St James's University Hospital, Leeds LS9 7TI

\section{Parental suicide}

Sir: The article by A. Ubeysekara (Psychiatric Bulletin, June 1994, 18, 340-342) highlights the importance of preventive work for bereaved families but does not mention a role for adult psychiatrists. Most psychiatrists will have patients who are also parents and who commit suicide. Parental suicide has been shown to relate to subsequent bereavement (Shepherd \& Barraclough, 1976) and parental suicidal tendencies to suicidal ideas in a non-clinical sample of children (Pfeffer et al, 1984). Adult psychiatrists need to consider such patients in the context of their families (Kissane \& Bloch, 1994) and arrange early appropriate intervention. The model suggested in the article may be useful in deciding on these interventions.

Kussane, D.W. \& BLOCh, S. (1994) Family grief. Brttish Journal of Psychiatry, 164, 728-740.

Pfeffer, C.R., Zuckerman, S., PlutchiK, R. et al, (1984) Suicidal behaviour in normal school children: A comparison with child psychiatric inpatients. Journal of the American Academy of Child Psychiatry, 23, 416-423.

SHEPHERD, D.M. \& BARRACLOUGH, B.M. (1976) The aftermath of parental sulcide for children. Brttish Journal of Psychiatry, 129, 267-276.

T. MORRIS, Hesketh Centre, Southport, Merseyside

\section{Psychotherapy training in Turkey}

Sir: We would like to expand on some issues concerning psychotherapy training which was briefly referred to by Samanci \& Erkmen in their article 'Psychiatry in Turkey' (Psychiatric Bulletin, May 1994, 18, 300-301).

Just as Anatolia, or ancient Turkey, was the motherland that gave birth to many civilisations, it was also one of the main regions where the art of medicine was skilfully practised and promoted. The Anatolians were concerned about mental illnesses and their treatments. For example, in the renowned hospital of the Asklepion 
temple of Pergamon, during the Hellenistic period $(1000-300 \mathrm{BC})$, the mentally ill were placed in a tunnel where they could listen to running water as they walked through it (Gokay. 1969). It was believed that this soothing expertence would help diminish the evil caused by wicked spirits. In another hospital - the Darushshifa of Edirne, the capital of the Ottoman Empire up to 1453 - the therapeutic powers of music and its ability to afford relief were well-recognised (Ozturk, 1990).

Following the foundation of the Republic in 1923 Turkey has undergone rapid developments in science and technology similar to Western industrialised nations. These revolutionary changes have resulted in a social life often at variance with centuries-long tradition. This has led to profound changes in the beliefs and value systems of the community. Such cultural upheaval can have an effect on psychological well-being at both an individual and a national level creating demands and challenges not previously encountered. The emphasis on biological aspects in psychiatric training is commendable. However, it would be a shame if this meant that the equally important psychological and social facets of training were to be neglected as expertise in these areas will also contribute to the health of the Republic.

Although psychiatry in modern Turkey is built on the fertile soll where psychological treatments were exclusively used and appreciated, unfortunately there is little if no provision for psychotherapy training in the formal training schemes. Very few trainees are fortunate enough to get supervision and theoretical lectures from trainers experienced in psychotherapy. Most of the therapists sufficiently qualified to supervise case work and teach are working independently of the university medical schools. Consequently, extra funding, time and effort are required by trainees to purchase what is offered by the avallable experts. Besides, there are always problems of lack of communication, standardisation and inconsistency with such extra-curricular pursuits.

As socio-cultural changes emerge in Turkish society, previous thoughts about psychotherapy being a luxury for a developing country are being reconsidered and psychotherapy is increasingly requested by both patients and trainees. Review of psychiatric training schemes and in-patient and out-patient services along with encouragement to establish university-affiliated psychotherapy associations may help to answer these demands. These changes will take some time unless Turkey produces mental health legislation that once again recognises the necessity of psychological treatments for her people and psychotherapy training for her future psychiatrists.
Gokay, F.K. (1969) Ruh hekimilgi sahasinda Turklerin calismalart. Tip Dunyast, 42, 526

OzTURK. O. (1990) Ruh Sagligi ve Bozuklugu (3rd edition). Istanbul: Evrim Basim-Yayim-Dagitim. P. 6.

Y. BerRaK Cigeroglu, Cerrahpasa Medical School, Department of Psychiatry. University of Istanbul, Turkey and *DECLAN M. MCLOUGHLIN, Institute of Psychiatry, Denmark Hill, London SE5 8AF

* Correspondence

\section{General practice training for psychiatrists}

Sir: As someone who undertook vocational training in general practice before beginning a career in psychiatry, I found the article 'General practice training for psychiatrists' by Burns, Silver, Freeling \& Crisp (Psychiatric Bulletin, May 1994, 18, 286-288) fascinating. Although there were minor problems, it suggests that it would be possible for many trainees in psychiatry to have experience of general practice for six months. I do appreciate the value of such a placement, and there is presently an excess of GP trainers over GP trainees.

The desirability of this is another matter. General professional training in psychiatry takes around three years: usually six six-month placements. Given that three will be in general adult/old age psychiatry, this leaves only three placements in which to gain experience in the other specialities/subspecialities. Surely the time to recognise the value of wider experience is when appointing people to the rotational training schemes in the first place.

Are the authors really suggesting that trainee psychiatrists would find six months in general practice more valuable than, say, six months in child psychiatry?

It is an interesting idea. Has anyone put it to the Professor of Child Psychiatry at St George's yet?

GaRY Sullivan, Princess of Wales Hospital, Bridgend, Mid Glamorgan, CF31 $1 R Q$

Sir: Dr Sullivan's point is well taken. Trainee psychiatrists do have to make choices. More importantly, the relative importance of different training experiences may change over time and may indeed be different in different settings.

The Royal College of Psychiatrists already recognises the relevance of general practice experience to psychiatric training by allowing for up to one year of time in general practice to be counted towards membership experience. The purpose of our study was not to suggest that psychiatrists should be obliged to have general experience but to explore one method of possibly providing it for 